\title{
THE DEVELOPMENT STORY IN THE REFLECTION OF HISTORY
}

\author{
Taupik Abdullah'
}

\begin{abstract}
Statement of Bismark, the Prusia chancellor was right, "Clever people," he said, "learn from his own experiece. I learn from other's experience". Other's experience? It means he learn from history, then he could unite Germany. Today we also face a problem in education. In this beloved homeland, history lesson has been ignored, eventhough this nation was formed from the understanding and awareness of history, and this country leaders have spoken about nation's character development. Someone with better understanding could explain the reason of this odd policy. Understanding and awareness of history are needed to overcome various problems faced by this nation. In this very obvious imbalance, do we need to wonder about the decrease of Human Development Index? In their release, UNDP explained that Indonesia curent (2011) posistion is 124 (index value of o.617) from 187 countries . Thus, when a personal and social conflicts that have been provoked by the unfair economy imbalance were related to the relgion and ethnic, a bloody conflict could not be avoided and even worse it was spreaded to various other problems. Many people had been the victims, not to mention the hatred in their heart, before peace could be realized.
\end{abstract}

Key Words: reflection of history, unfairness of socio-economy, internal conflict, vigilante, democracy, awareness of history, local autonomy.

\section{Reformation in the Current Worry}

A few days ago the writer recieved an interesting Youtube video link. In brief, the video was merely about an American journalist visiting Indonesia. Nevertheles, the message of the video had caught the writer attention. The journalist (and the tv crew) who visited Indonesia because he saw a news about "an Indonesian smoking baby" on tv, that had become an international sensation. This video on youtube started with a scene of an Indonesian boy smoking in a "sophasticated" way. Apparently, the three years old boy consumed two packs of cigarette a day. The journalist was really amazed because he had noticed an intensive 'no smoking' campaign for years in America and many other countries. There is no cigarette product billboard in America. A pack of cigarrate price in New York City started from $\$ 12.00$ or about Rp. 110.000, - , plus the $\$ 1.35$ tax.

1 Prof. Dr. Taupik Abdullah, is a prominent scholar of History and Social Science in Indonesia. His aspiring studies on Islam in Southeast Asia and local history of Indonesia are highly praised at home and abroad, and contributed greatly to the further understanding of Asia. For academic interest, the author can be contacted through his email address: drtaufikabdullah@yahoo.co.id. 
Indonesia has made international news because a baby boy was casually smoking like and with adults.

Thus, the journalist come to Jakarta. As soon as he arrived in Jakarta, he said he was like stepping back in time. He saw cigarette billboard everywhere. The more he explored Jakarta the more he realized about the power of the cigarettes' network. In front of a school he saw not only a cigarette advertisement with the cowboy picture, which had been long ago gone from his country, but also the cigarette seller. From an interview with an anti-cigarette community he knew that one of four boys, with the age range from 13 to 17 years old had already enjoyed cigarette. "This is a poison", said a scientist who was appeared two or three times in the youtube video, "that could kill one billion people in a century all over the world, which eighty percent is from the developing country".

In fact, while the developed countries were able to decrease the cigarettes influences, it grew bigger in the developing countries. That was the reason Philips Morris bought Sampurna. The west capitalist expanded their network to the developing country because their chances in their own countries had become narrower. But, how about the future of that developig country, how about the future of Indonesia? Who was the richest man of Indonesia according to Forber magazine? Weren't the first and the second richest man of Indonesia the cigarettes company owners?

In his letter, the friend said that he was really sad to see this video about cigarette. He visionized a darker future if this habit would not be going to be changed. Suddenly the writer of this article also felt the dillema in our society. What would the tobaco farmers and the cigarette makers do for their living if cigarettes would be going to be limited or prohibited?

Maybe the writer was in a bad luck morning, the writerhas just finished watching that video about cigarette on youtube, another email came. It was about a $\mathrm{BBC}$ programe that launched a story of a London binman who was sponsored to come to Jakarta and experienced the life of a fellow binman in Jakarta. The London binman was really touched by his new experience, he often dropped tears. He could not express his feeling after seeing and also experiencing the poor life of his colleague. He could not imagine a life as the was experienced lived by the Jakarta binman, who is now his friend.

After seeing the video, the writer concluded that the ironic aspect about Jakarta's life, and other big cities in Indonesia, is unimaginable. There were many street vendors that sell afordable daily needs for poor people like that Jakarta binman, at the same time there were also many luxurious malls as luxury as the malls in the developed countries or even better, which sells luxurious and branded items. Thus, it would not be weird to read a survey that said 80 percent of mall visitors are those who only want to go sight seeing. We need a high imagination to accept that those who enter the luxurious shops are those who live in a really higher social class.

From the footage, it can be seen that the poverty in big city was high, and the social-economy imbalance aspect was also very obvious. Eventhough the 
"middle class" - a level of having economy capability - has increased, the extreem social-economy imbalance has also been the part of our nation's life reality. The extreem poverty is a reality that cannot be hiddened eventhough the statistic says optimistic figures. No wonder most people would be amazed if the gap between the haves and most common population is very extreem in the country which the "social justice" is one of its national foundations. A study said that today in America, the average of 500 richest person wealth equals to 20.000 times of the average people wealth. In Singapore, according to this study, average wealth of 500 rich people equals to 25.000 times of the average citizen of Singapore. Then, what about the Indonesian wealth comparison? It is said that the wealth of 500 richest person of Indonesia equals to 600.000 average Indonesian (Winters). No wonder that Indonesian politic world today, after the political reformation era, is steered by these Indonesian richest people.

In this very obvious imbalance, do we need to wonder about the decrease of Human Development Index? In their release, UNDP had explained that Indonesia curent (2011) posistion is 124 (index value of o.617) from 187 countries (Susanto, 2011). Lower than the position of 2010, which was at 108 of 169 countries. This means, Indonesia was the fifth of the ASEAN countries rank - Singapore position is 26 (o. 866), Brunei Darussalam position is 33 (o.838), Malaysia position is 61 (0.761), Thailand position is 103 (0.682), and Philippine position is 112 (o.644). Vietnam (120), Laos (138), Cambodia (139) and Myanmar (112) are lower than Indonesia. This UNDP ranks also shows an irony. The decrease of Indonesia's human index happened in the education field. Eventhough the amandement said that the education budget is $20 \%$ of APBN the State's Budget (Media Indonesia, 2011). However, the average index calculation was based on the education year experienced by most population, which was 5,8 years in average for Indonesia not even graduated from elementary school. This fact shows an extreem social imbalance. It reveals more that the exclusive private schools and universities, or study abroad is affordable only by the higher social class, which is also more exclusive.

After all the struggles in politics, social, and economics, why is there no improvement in the Indonesia's current structure? The imbalance and unfairness of socio-economy, the low education indexes, and the story of a baby boy smoking seems to make our future darker. How important is the present that future only owned by who can afford to climb to higher economy class? What are the impact of all struggles in politic, social, and economics on the current Indonesia? Why there is no improvement on the lives of Indonesia today. The problem in economy, law, and other socio-cultural lives seem to made our future darkness.

If observation and index are not enough to understand the current situation in this country, think about the meaning behind every current occurances that have come to our concern. Eventhough geography, and also history, has become an "unimportant" subject in the elementary and secondary education level, the geography knowledge in the common society has developed and improved faster. 
Today, who has not heard the names of Puncak Jaya, Sape, Bima, and Mesuji (which apparently located in two provinces, Sumatra Selatan and Lampung), and Sidomulyo. Cikeusik, Cirebon, Bali, Bireun, and Aceh Besar, even Sumenep had exposed themselves through various stories that makes the news. Even a little town like Bekasi also exposed themselves by their own story of thousand labors blocking the main road in middle of January 2012, demanding for proper wages.

These cities seems to be proud to put their names in the sad side of the Indonesia, side by side with Ambon, Ternate, Halmahera, Palu, Sampang, Sampit, and Aceh. However, they have stepped back from today's headlines.

The names of those cities are not easy to forget, they have become the symbol of conflict and pathetic events which is called as the internal conflict. It is really tragic when reformation of the state's order is directed toward a more democratic nation has become everyone's worry, some area had this horizontal conflict which caused merely by a simple matter. Thus, when a personal and social conflict that have been provoked by the unfair economy imbalance were related to the religion and ethnic, sop a bloody conflict could not be avoided and even worse spreaded to various other problems. Many people had been the victim, not to mention the hatred in their heart, before peace could be realized.

The religius-ethnical conflict has left their traced when intolerant spirit shows its face. Many people had been kicked out from their mosque in West Java, Lombok, and other area. Even the ethnical jokes about innocent Madura has also losted their humors. No wonder a research institution state that some regions seems competing in showing their intolerance toward differences. The goverment do nothing but shaking their heads, considering all the conflicts are some common events. There is even an organization who claimed to defend a religion act like a vigilante. To realize their own order, the members of this organization did violent acts without any rights, and were disobeying the law of this country.

There are also some terorists who claimed their action was in the name of Allah, yet they did violent toward human. If their operation to bomb the cafe and hotels where many non-moslem foreign tourists were hangout could be considered as some foolish act, what about the teror occured in the mosque during prayer, as happened in Cirebon?

Each area had its own kind of conflict. Some cases of land space that keep decreasing could also be the cause of conflict. When the goverment, in the name of development, try to open a chance for plantation or mining business, even to protect the plantation or mining company'sillegal operation, that had caused worry to the local people and may end up in a conflict. In this case, the local people felt that governmant had no care for them, their worries had uncovered that the state was in the big company side. The people became angry, and released the anger into violent acts and victim had fallen one by one. If that was the case, whose to be blamed? Whose to be blamed when the Bima regent's office was burned down by the local people, who will take the responsibility if the local people was aiming their angers to the officers that suppose to take care their security? 
Forest should not be exploited without considering the society who lived in its environment and in the environment conservation. However, human greediness in increasing their current financial level could threat our future. "Indonesia is one of the country in the world that is experiencing resource curse." Said Lex Riefel (VIVA news, January 3oth, 2012), An American economy and politic expert. He continued, "Indonesia is not handling their natural resources effectively, this country is destryong nature by over-exploited it, and does not manage the natural resources for its people interest ... Indonesia will be a new problem for Asia."( VIVA NEWS, Monday, January 3oth,2012). (endnote iii). If this the case, do we already forget the Article 33 Paragraph 2 of the Constitution, which claimed to be written by Bung Hatta himself? If this constitution will be ignored, why don't claim it openly as pure capitalistic?

The current situation story has not ended yet. Who doesn't know Gayus Tambunan, a young civil servant who manipulated tax, attorney, judiciary, and immigration? Who doesn't know Nazarudin, the other coruptor names? Is there any other bank in Indonesia as famous as Bank Century, eventhough she has changed the name? And the latest was the case of Wisma Atlet?. Many comments and views have been conveyed about all of these cases, but there is only one conlusion, corruption is very familiar currently, eventhough the Reformation movement was launched with the foundation of eliminating coruption, collution, and nepotism in Indonesia.

Covered with any kind of colors, democracy and local autonomy is an antithesis of the centralized authority system. But, what can we say if the autonomy and democracy occured right after the authoritarian fall is in fact opened the door to the local conflict, for a certain people interest? In this kind of situtiation various local conflicts occured in certain places. The supporter of a certain legislator candidate got mad after their candidate had been defeated. Another case was the emerge of violent act threat during the regional head election when the monopoly goal could not be fulfilled. A sinistic question arose, after about forty years in the authoritarian and centralistic system, how ready is this nation to return to democracy?

Even the real situation could not be imagined, but a comment which said that Indonesia is no more that a plane in auto pilot mode or a ship without a captain has emerged some worries. This seems true because more often people find situations that have no appearance of goverment, eventough they are realy needed. Where is the government when labors and their employers had caused a conflict that bother the public order? Where is the government when some people who don't conform with other's belief were attacked? Therefore, it can be understood if a survey said that the people respect to any governement agencies has been decreasing. Is it the people fault when an elected institusion such as DPR (parliament) has been sinically talked by others? 


\section{Hope, Success, and Worry}

In some of his speech when he was till the leader of a national movement, Soekarno, the proclamator, had visioned that independence would be "a bridge" from the dark present into a bright future. The future he imagined is the present we live in today. But, where is the bright future? What has this country been through since the fulfillment of the goal, as mentioned in the Opening of the Constitution, that was fought with sacrifices and patriotism?

After years in revolution to defend the nation's Proclamation of Independence with "tears and blood", an December 27th, 1949, this nation gained its oficial recognition. Suddenly this new nation state experienced a situation of, as Herbert Feith (1964) said, a "nationalism was at its zenith". The future optimism was ahead, Indonesia was equal with another nations. At that moment, some artists confidently claimed a manifesto of "We are the legitimate world culture heir". Why not? Weren't they also the citizens of a democratic country that was developing their future? In a blink the unity of Republik Indonesia Serikat - a compromised country - was threatened by a movement formely known as KNIL in West Java and South Sulawesi. However, the threat only accelerated the change from RIS and back to the unitary state. Meanwhile, many universities were established, not only in Java, but also in Sumatra, Sulawesi, and Bali. Eventhough threat was still there but a bright future was strated in the context of state's structure in the form of parliamenter democracy (Abdullah, 2009).

Various problems in the national revolution era were needed to be hanlded as soon as posible. The political community that was divided during the revolution era demanded their legality, Darul Islam had been the channel of various political worries in certain regions (West Java, Aceh, South Kalimantan, South Sulawesi). In this situation, a separatism movement, Republik Maluku Selatan, threatened the state unity. Meanwhile, the former soldiers positioned in the nation's constelation that interested in modernizing the army was also need to be handled. When parliament seemed to only concern for their parties, how to avoid this parties competition with the interest of the army modernizing?

When various conflicted demands must be faced, the parliamentary system life had to face a bitter truth. Ideology clash could not be avoided in developing the dreamed future, and the hope for the future could not be ruined. The general election had shown that Indonesia consisted of various political and cultural element with the modern pasion of different future. Therefore, the political stability was tested, when obstable in deciding the nation's foundation occured and various local resistance could not be handled expectedly. Moreover, Irian Barat was still under the Dutch's authority, an intiative was needed. However, when a brave act had emerged, constitution must be broken. A political anxiety transformed into rebellion, foreigners intervention threatened the nation's unity. 
During the chaos President Soekarno released the President's Decree of 5 July 1959. With the argument of returning to "the national identity", they left the parliamentary system which mentioned as the "West liberal tradition". Another change had occured, as always campaigned, "the revolution hasn't been over". Return to the the 1945 Constitution was "the rediscovery of our nation". However, that moment was also the end of the democracy life, eventhough the name was mentioned in the term of "Demokrasi Terpimpin (Guided Democracy)"

That's how the parliamentery democracy which full of national future idealism ended. The democratic idealism of political system did not conform with the ideological clash and political competition and various region's local anxieties. The general election which was considered as the cleanest election, only showed the complexity of political aspiration and stream diversities. Not much development could be done in the era fof ull of idealism and idelogical as well as political conflict. This multidimenstional conflicts seemed too hard to be handled by patience only. Since the Demokrasi Terpimpin (system had started, that's the initial toward a greedy country. Step by step, in a short time, the goverment positioned itself not only as the only owner of authority and economy system, but also the hegemony discourse and determinant of the nation's collective memory. Claiming himself as the center of the legal nation's authority - as the president and the commander in chief - and also the personification of a maintained ideology - the Revolution Highest Leader and "the Conveyor of People's Opinion" - President Soekarno did not only eliminate trias politica - dividing the state's duties as executive, legislative, and judicative - but also visioning the world in conflict. Therefore the principal ideology of an impossible harmony betwen the New Emerging Forces and Old Established Forces was the foundation in understanding the reality and political dynamics.

In this kind of concern the revolution spirit was flamed. Under this kind of concern, the focus of development program was Nation and Character building. For this purpose, indoctrinating the youth was needed. Therefore, various symbols of the national pride were developed. The DPR building (formerly CONEFO building), national monument, Istiqlal Mosque, and the city of Palangkaraya were Bung Karno's vision to enhance the pride of Indonesia as a big country. However, development of all those sites were finished after the end of guided democracy period, and shifted to the Orde Baru (new order) period. Meanwhile, the economy was slipping down and the society welfare was not even better. Queueing for a little amount of basic needs was considered as one of this nation's culture.

In this revolusionar situation, as well as the low economics welfare, the Dutch had politically announced Irian Barat as "an independent country". With "tiga komando rakyat (tritura)", a war was started. The UN (and the United State of America) interverned, war between Indonesia and Dutch was ended with the New York agreement (1962). Indonesia was assigned to perform the UN trusteeship of Irian Barat until the Act of Free Choice on 1969. 
The year of 1962 was an exceptional year. That was the year when Indonesia hosting a big event of Asian Games. Indonesian athletes never had such a great achievement as achieved during the Asian sports event hosted in Jakarta at that time. This year was also a golden year for Indonesia. New era of national life was visionized. However, time passed quickly. In a very short time, the 1962 became the year of wasted opportunities. In this year a political confrontation toward Malaysia was acted. However, the "cofrontation", which was performed as the New Emerging Forces movement pioneer, was not only caused Indonesia to step back from the international community but also grew separation seeds in this nation.

When the time had come, the "nightmare" occured and the saddest tragedy of this nation had begun. Who had ever wished that the event in the 3oth September night, approaching the 1st October in 1965 would never happen? How caould we avoid to ignore the situation of the days and months full of sad conflict and murder? This tragedy could not be avoided. And as the result, The Guided Democracy was just a history. The Father of the Nation was left alone, before The Creator took his life. Meanwhile, the New Order had come with its promise to fulfill the Proclamation promises and be loyal to the 1945 Constitution and Pancasila.

With the end of the Guided Democracy era, which also called as Old Order, the era or the discovery of our revolution was also ended and a period called national development began. The world was not visioned as field of never ending war and conflict between NEFOS and OLDEFOS, but a future market and partnership in the development and economy improvement. In this era, the revolusionary appearance had lost its appeal. In this era, there was no political "confrontation". Ideologically and politicaly the revolution position was replaced by the technocrats - a new profession introduced in the popular politic dictionary. The technocratized developmentalism era had began under military domination in its double functions. However, the the nation's character concept was maintained, eventhough the term was changed into the nation's identity. With the argument of the cultural originality, not copied from the West, could an authoritarian power be maintained?

There was, a time, when the authority colored with "revolutionary authoritarian" had been focused more on the development supported with an authoritarian and centralized authority system. There was no "revolusionery command" to be obeyed because centralized "the development program" had begun. Any procedural principals of 1945 Constitution was performed - the general election, GBHN (the Outline of State Policy), President elected by the MPR (People's Consultative Assembly) - but the final result came from behind the curtain. The Mandatory of MPR was the authentic source of power. In this kind of situation the nation's "unity" was maintained in the requirement to obey to the principles of Pancasila, for any and all social organization, as well as a minimized party member which only consist of the "spiritual-material" party, PPP; "material- 
spiritual" party, PDI; and Golkar, the party that was not really a party because it was the electoral machine of the government. To ensure the expected performance of all these, the training for internalization and Implementation of Pancasila/ P4)" was held. Every students, military officers, and organization and party activists were required to attend this $\mathrm{P}_{4}$ seminar. There was also $\mathrm{BP}_{7}$, an organization for the $\mathrm{P} 4$ seminar implementation, that was established through the level II regions. In its peak development, the power system was not only about uniformity and centralising the regional government, but also involving the villagers to be a part of uniformized government system. Isn't the uniformity which centralized the national development called "continuity" easier to be performed?

The New Order of the "national development" was not only a legitimation foundation of its apperance but it is also as a political direction that was performed in full focus. There was BAPENAS that played an important role, like GBHN that was the main guide of MPR's tasks, eventhough the document was prepared by a team of experts. Every departement, or university must have research and development center. Every region must have BAPPEDA. The national development was not only a program to perform, but for the New Order era it was an ideological foundation of it legitimated appearance.

We must admit that this New Order era was under the direction of President Soeharto was the regim that changed the Indonesia map dramatically, disregrading any comment of his leadershipness. During his authority, new cities, wheter it was the satelite of an old city or not - such as Batam - were developed well. Meanwhile, the old cities were better, those cities became the economy center for the regions sorrounding it. These cities were growing and more modern. Road networks and birdges were developed everywhere. In the Orde Baru era the regions from the begining of the west side through the end of the east side were connected. Plane had become more familiar for most Indonesian people. In the New Order era Indonesia received an international award as the country that was able to provide rice independently and the success of family planning program. Schools were available up to remote areas. Universities were established in every province and most of the region's capital cities, owned by the government or private. Health centers were available in almost every strategic locations for villagers of sub-urban areas. Meanwhile, the GNP was also increase 7 percent per year. Many foreigners observers was undoubtly called Indonesia as the "emerging Asian Tiger".

Unfortunately, behind all these success, another problem of social development was also arise. After the euphoria of equity and growth, fairness or welfare, and the prediction of trickle down effects, a social-economy dynamic was happened. The welfare, economically, was mostly occured at the top level with a limited access to the lower level. Therefore, the governement was increasing its power, hard to be lowered, and become more oligarchy, which was weakening the border of political and capital power. Thus, the social class gap was wider. When the traditional value of "family nation" has weakened the modern border 
of state which is based on law, various coruption, colution, and nepotism practice were unavoidable. The forming and affirmation of oligarchy happened naturally. That is the reason of New Order development, which was intended to obey the 1945 Constitution purely and to use Pancasila as the main principle, slipped to the oligarchy system, eventhough they tried hard to conduct the enlightened depotism. The New Order era was trying to be good to people whithout involving the people.

Authoritarianism and centralism under the spirit of technocratized development was a big bet to be used in the effort to face the future, which can only be predicted without any confirmation about it. This situation was more serious because it was maintained under the authority of discourse system hegemony. In this well maintained tradition, there were no opposite opinion could be spoken up, not to mention that to express oneself as the legitimate alternative in the development strategy formulation and brainstorming. Thus, if everything was centralized. Only one point of power and an opinion would be recognized when it was in conform with a particular assumption, there would have been a slipped in facing the challenge outside the considered legal paradigm. In time, the block in creativity would not only cause intellectual weary, but also frozen the imagination to face unfamiliar challenges, that would also affect social-economy life. When that happened, various scenarios of defeating began. This was what happened during the monetary crisis, that was began in Thailand but strucked Indonesia with a massive power. This monetary crisis had been the whip to build a mass power. Initiated by university students and any other intellectual people, the New Order Government had a limited choice. Even though the President was elected for the seventh time, he was forced to step off his position, and he was failed to fullfileed his abition as the pandito. Indonesia entered the reformation era. The New Order had ended, at least in the political system

However the political tradition maintained over forty years - since the President Decree 5 July 1959 until 21 March 1998 - had not gone. In this situation this nation had a conflict between the reformation requirement and the authoritarianism that has been a private principal and tradition. Therefore the border between reformation and democracy euphoria was not clear and sometimes even worse. A question emerge: when and how will this democracy be gone and can the true reformation can be conducted independently?

\section{Between Worry and Optimism}

When it was announced that President Soeharto stepped down from his posisiton, the university students that had been sitting on the DPR Building complex for several days showed their grateful and cried. The first win againts Coruption, Colusion, and Nepotism pratices, as well as returning the country to democracy under the rule of law awareness had been fulfilled. However, for some elite people, the power shift from President Soeharto to the Vice President B. J. 
Habibie was considered not more than an illegal act and undesireable. Wasn't Habibie educated by Soeharto? Therefore, there was a movement to eliminate this new president. But this movement was blocked by constitution requirement. An idea about a temporary aunthority system was also proposed. However, the democratic principal from those who wanted the "pure democracy" had been problematic when they refused to have a dialogue with the president. In time, it was proven that their attitudes was only symptomatic, which was caused by the authoritorian system implemented in the context when tradition and democracy requirement were going to be recovered. It must be admitted that ambivalence was a characteristic of a transition period.

Meanwhile, in a short time, without prior experience, President Habibie introduced various laws in acordance with the ideology of the 1945 Constitution. Regional autonomy, press freedom, association rights, and others were introduced. Bank Indonesia was seperated from the cabinet. The $\mathrm{BP} 7$ was disbanded, symbollically announced that the "greedy state" era, which controlled everything, had ended. Regardless of every dicussion about political wisdom of fundamental mistake, when President Habibie gave the freedom to the people of Timor Timur to choose between independent or stay with the Republic of Indonesia, implicitly he followed the firts sentence of the Constitution Opening - "independence is the inalienable right of all nations". He had to pay a high price politically. His accountability speech was rejected. The Habibie government had ended, but the reformation era must follow the historical pace.

When everything has been explained historically, what can we learn from that fresh experience? Historically, it can be said that there is no country or nation that never experienced a dramatic tragedy era, and even worse happen like Indonesia. When Demokrasi Terpimpin announced its era by eliminating the parliamentary system, Indonesia entered a long period of the implementation of "Military Law". In this era some parties were disbanded, some political party leaders and society figures were ordered to take a "rest" in military prisons. However, when the Demokrasi Terpimpin was approaching its end, the worst tragedy hapened. The biggest wish to forget the tragedy could not be fulfilled because the question of "why that should be happened?" is still there. Now and then many arguments have been conveyed to cover the hatred.

An old story seemed to reoccur when the reformation movement won there is a price to pay for a fundamental change. At this moment the democracy euphoria was uncontrollable. Sundenly there were many new parties born, contradicted the older idealism, the three parties of New Order- Golkar, PPP, PDI - separated in their own ways. These parties had more fraction. Further, the word "leader" seemed gone from the political discourse, replaced by "political elites" in various discourses and political critcism. The leadership relationship was in crisis. Thus the crisis of mutual trust had also appeared. Apparently when the "lid of differences box" that was maintained closed during the New Order Era was opened when the era had to be ended, at that moment the society realized 
that all this time they were not really knowing their own mind orientation. It has been revealed that the "unity", which was always praised and obligated, was only a camouflage of differences that never had a chance to understand and adapt to each other. The almost total domination in the New Order era had made everything silent, as if everything was just a loyal follower of the authority. If the cover had opened and any and all differences appeared, should we wonder why the crisis of management was also appeared in the nation's life? How long can this simple conflict be resolved?

In this situation, event though one or two presidents have recieved the people's trust, the social-politic symptoms, as well as the government administration, and a situation that will result in the spiral of stupidity could not be avoided. Often, a stupid act also addressed stupidly? Before we understand the true problem, two villages neighbouring each other had made a war or a party had disbanded itself, many other worse things could happen. Or, as often occured in the community called the political elites, a "stupid" statement was addressed in a stupid way. Before we really realized what had happened, there was a conflict among the political elites, that might obstruct to solve the nation and state's problem. The participant and the observer had lost their focus about what was the real matter.

Another fundamental question emerged. Is our beloved homeland cursed to stay in the circle of the hope to change but always slipped back to disappointment? Isn't with all events happened, it seemed that no matter what improvement this nation had we will always getting back to no where? We are always comeback to the begining point. Thus, should we keep hoping for a bright future for our nation's life?

Have this brief analysis revealed the true reality? Or, were all these just a short social-politic event and phenomenon that had a deep impact? Are we easier to remember anything touched our subjectivity feeling and our belief? Then, is history, in fact, not only a note about a series of events, one damned thing after another? History is not only a written note about a sequence of events about various stories of crisis and conflict, eventhough those events were usualy noted and remembered. History does not leave a casual, nondramatic event unnoted. How would our optimism of the future be, if this nondramatic event was left unnoted?

Apart from all the political and social crises, and all disapointments, how could we easily forget various fundamental successes that was recieved and was fought hardly by this nation? For example, how many ethnic groups we have in this place, as the part of what Ber Anderson called "imagined community" or "nation", how many languages which also the important elements of Indonesian language development? Our diversities are very complex, how can these - apart from those conflicts that happened sometimes - be the part of the nation-state of Indonesia? This question might not emerge if Indonesia is hegemony attention, because it is considered as usual. However, if we compared to another nation's 
experience (Uni soviet, Yugoslavia, British India, and others), what kind of answer could we get? Various crisis that resulted in seperation had happened since the Proclamation of independence, how could this unity be maintained and even stronger? When was the Independence Proclamation announced how many young people of Indonesia had studied in university? Today, which university could reveal the exact amount of the youth studied there, which used to be valued as a luxury? There could be many dissapointments about the limitation to go to university, not to mention the limitation of work field, this achievement cannot be ignored. When intellectual people have become a big community supported by various, depth sience and technological skills, that is the moment when there is no reason to despair. Eventhough to develop the intelligent community consist of all ethnic groups is still a long way to go. But Jakarta - if it could be an example was merely a big village in 1970 , look at her today. Let people think in which rank Jakarta is as a metropolitan city. Hospital, big and small, luxuryious or simple has been common, eventhough broken houses that express poverty have not been handled properly. Jakarta is merely an example, could not be the best. However, we cannot ignore that a fundamental change had happened.

Various crisis, the bloody one and threaten the unity and the nation's existence - happened now and since the national revolution occured. The final words remain "Indonesia survives". How many rebellions or "the revolution in revolution" must be faced or deviation of the national goal had been handled without decreasing the nation's integrity? Every problem could be handled properly, eventhough it should be faced with a great suffer. If we put more consideration for this, the conclusion should be the optimism toward the nation's future.

Was our move to handle the problem we faced just a cliche? But we should remember that the purpose to develop this nation-state is mentioned in the preambule of the constitution. This is still relevant as guidance for the present as well as the future. Besides "protecting all the blood spilled and the nation", "improving the people welfare", and "involved in esuring the world peace", the purpose of this nation was also clearly mentioned in four words "improving the nation's intellectuality". What is this intellectual nation's life according to Pancasila, as mentioned in the Constitution preambule.

\section{Conclusion}

Various visions and theories have been conveyed, if only the nation's experiences can be studied and understood, it would be revealed that any slogan or attitude can not be valued only by the truth concept. When it is confronted to the public, there is no single truth. If the truth belief is forced, conflict can not be avoided. Who is right, who is wrong? Many example in the historical life of a nation can be explored regarding this problem. Is rebellion wrong? Or, are they just an act based on the "trurth" they believed? 
The same thing occurs in "fairness". What is fairnes for all? Laborers consider it would be fair when their wages is raised, while the employer considered it is fair when the cost they spend will invite more money, not the otherwise. There are many other examples. If each other fairness concept is different, eventhough all are based on the truth they believed, mostly will end up in a conflict. This is the face of this country "decorating" the printed and elctronic media. Both great priciples will have their meaning if they are guides by "wisdom". Unfortunately, if it is allowed to re-study the history, the conflicts and many unwanted matters happend when "wisdom" was left in the process of determining the social-politic attitude and strategy.

The wisdom, along with "truth" and "fairness", will determine which is good and which is bad. The wisdom is the ability to choose the best of various alternative available. Wisdom is also to let go and deciding attitude when there are various ethnical dilema to be faced. Therefore, it can also be said that wisdom cannot be gained through deep meditation or asking the "fortune teller", but it's about the society, nation, and humanity understanding. Wisdom cames from a depth understanding about the nature of reality structure and dynamic. Maybe a simple statement of Bismark, the Prusia chancellor was right, "Clever people," he said, "learn from his own experience. I learn from other's experience". Other's experience? It means he learned from history. And he could unite Germany. The Prusia kingdom was ended but Germany has united, emerged as a big Europe power after defeating French (1870). This is just an example of the history wisdom. Imagine how this nation's independence pioneer got the idea of an independent nation. How could they get a wise inspiration toward this nation independence?

Today we also face a problem in education. In this beloved homeland, history lesson has been ignored, eventhough this nation was formed from the understanding and awareness of history, and this country leaders have spoken about nation's character development. Someone with better understanding could explain the reason of this odd policy.

Return to the main discussionn, the conclusion of this discussion is simple and common. Truth must be enforced. Therefore, corruption must be eliminated. We should always fight for justice. But without wisdom, despite all of their details, both can be meaningless. Wisdom is always guidance. These three elements create what is called "intellectual nation's life". Finally, pray to God will be the habit of people with faith.

\section{REFERENCES}

Abdulah, T. (1985). Ilmu Sejarah dan Historiografi (Arah dan Perspektif). Jakarta: Gramedia.

Abdullah, T. (2009). Indonesia. Toward Democracy. Singapore: ISEAS. 
Carr, E.H. (1961). What Is History. New York: Penguin Book

Feith, H. (1964). The Decline of Indonesian Constitutional Democracy. Ithaca, New York : Cornell University Press, 1964.

Gottschalk, L. (1985). Mengerti Sejarah. Jakarta. UI Press Susanto, C.E. (2011). Indeks Pembangunan Manusia Indonesia Anjok ( writer:), Media Indonesia, Nov 4, 2011

Kuntowijoyo. (1995). Pengantar Ilmu Sejarah. Yogyakarta: PT Tiara Wacana.

VIVA news . "Indonesiia Bisa Jadi Masalah Baru Bagi Asia”. January 3oth, 2012.

Media Indonsia, November 4th, 2011.

VIVA NEWS. Discourse \& Analysis. "Indonesia Bisa Jadi Masalah Baru bagi Asia”. Monday, January 3oth. 2012.

Winters, J.A. "If Indonesians are going to find a candidate to ooppose the oligarchs, they need to start organizing now", 